\title{
EXÉRCITO E "POLÍCIA": OS CONJUNTOS TECNOLÓGICOS DO ESTADO MODERNO E A CONTEMPORANEIDADE DO NÃO COETÂNEO
}

\author{
Ythalo Frota Loureiro ${ }^{1}$
}

RESUMO: O presente artigo tem como objetivo explicar as origens do exército permanente e da "polícia", considerados como os dois conjuntos tecnológicos repressivos que asseguraram o Estado moderno. A pesquisa é bibliográfica e possui como referenciais teóricos as ideias de Michel Foucault e Louis Althusser sobre as referidas instituições; e o conceito de Ernst Bloch sobre a "contemporaneidade do não coetâneo". Como conclusão, verifica-se que uma teoria sobre o exército permanente e a "polícia" deve reconhecer seus aspectos contraditórios, pois são instituições que transitam entre o Ancien Régime e o Estado liberal para sustentação da ideologia burguesa.

Palavras-chave: Exército; Polícia; Estado moderno; Contemporaneidade do não coetâneo.

Title: ARMY AND "POLICE": THE TECHNOLOGICAL SETS OF THE MODERN STATE AND THE CONTEMPORANEITY OF THE NON-CONTEMPORARY.

ABSTRACT: This article aims to explain the origins of the permanent army and the "police", considered as the two repressive technological sets that ensured the modern State. The research is bibliographic and has as theoretical references the ideas of Michel Foucault and Louis Althusser about these institutions; and Ernst Bloch's concept of the "contemporaneity of the non-contemporary". As a conclusion, it appears that a theory about the permanent army and the "police" must recognize their contradictory aspects, since they are institutions that transit between the Ancien Régime and the liberal State to support the bourgeois ideology.

Keywords: Army; Police; Modern state; Contemporaneity of the non-contemporary.

\section{INTRODUÇÃO}

Exército e "polícia" são instituições facilmente identificáveis na maioria dos países. São órgãos centrais dos Estados contemporâneos destinados à defesa externa e à manutenção da ordem pública. Tais instituições garantem os meios coercitivos do Estado para fazer cumprir a constituição e as leis vigentes. O exército e as polícias, em sua grande maioria, organizadas no formato militar ou paramilitar, asseguram a coexistência social em meio democrático ou, simplesmente, a convivência entre países de diferentes regimes políticos e o controle social sobre o comportamento dos membros da sociedade de cada nação.

\footnotetext{
${ }^{1}$ Promotor de Justiça lotado na $111^{\text {a }}$ Promotoria de Justiça de Fortaleza (com atuação junto as Varas do Júri de Fortaleza) e Mestrando do Programa de Pós-Graduação em Direito da Universidade Federal do Ceará (20202022). Lattes iD: http://lattes.cnpq.br/6387713593384966. Orcid iD: https://orcid.org/0000-0001-8605-7208. Email: ythalo.loureiro@mpce.mp.br.
} 
O presente trabalho tem como objetivo iluminar as origens modernas do exército e da polícia, considerados como os dois conjuntos tecnológicos que fundamentaram o Estado moderno: o exército é a força militar que garante a integridade externa contra invasões estrangeiras; e a polícia, aquela que sustenta a coesão interna de um território. Ocorre que a exposição das instituições é realizada a luz do que se convencionou como "contemporaneidade do não coetâneo", ou seja, a convivência de sentidos contraditórios da mesma realidade. Assim, se procura demonstrar que as concepções modernas destes dois conjuntos tecnológicos sobreviveram na contemporaneidade e com ela faz um contraponto.

A pesquisa é bibliográfica, tem como referenciais teóricos as ideias de Michel Foucault (em "Segurança, Território, População"), que considera o exército e a polícia como conjuntos tecnológicos; de Louis Althusser (em "Iniciação à filosofia para os não filósofos"), que os considera como aparelhos repressivos do Estado; e de Ernst Bloch (em "Heritage of our times") que desenvolve o conceito de "contemporaneidade do não coetâneo". O texto ainda é complementado por outros livros e artigos sobre as temáticas mencionadas. A hipótese trabalhada é no sentido de que o exército e a polícia permanecem na contemporaneidade com as funções que justificaram sua existência no Estado moderno.

Deste modo, na primeira parte, o exército e a polícia são apresentados como estes dois conjuntos tecnológicos repressivos. Na segunda parte, o significado de "contemporaneidade do não coetâneo" serve como crítica ao modelo de coerção adotado pelo Estado moderno e evidencia as contradições do Estado liberal.

\section{EXÉRCITO E POLÍCIA COMO DISPOSITIVOS TECNOLÓGICOS DO ESTADO MODERNO}

Em uma definição bem simples, o "Exército é a força militar típica da terra, preparada e equipada para desenvolver operações de defesa no território nacional e de ofensiva no território inimigo." (BOVA, 1998, p. 504). O exército é uma das três forças militares, ao lado da Marinha e da Aeronáutica, contudo é a parte mais importante em termos numéricos. Além das Forças Armadas, em geral, há corpos armados, civil ou militares, encarregados, principalmente, de tarefas de ordem interna. Estes corpos armados desempenham funções 
típicas de polícia e sua organização depende das experiências e escolhas políticas de cada nação (BOVA, 1998, p. 505) ${ }^{2}$.

A polícia, no seu conceito mais difundido, é "uma função do Estado que [...] visa a pôr em ação as limitações que a lei impõe à liberdade dos indivíduos e dos grupos para salvaguarda e manutenção da ordem pública” (BOVA, 1998, p. 944). Neste sentido estrito, polícia diz respeito à segurança das pessoas e da propriedade, à manutenção da ordem pública e da tranquilidade e a proteção de qualquer outro bem tutelado pelas leis.

A "polícia" moderna é a marca de uma mudança de cultura jurídica. Antes a boa organização, entendida como "política", estava dispersa na oikonomia (ou saber do governo doméstico) e na prudentia governativa. A ideia de "polícia" como "bom governo", "ordem", "boa ordem", "civilidade" e "urbanidade" persistiu até 1750. Contudo, na segunda metade do século XVIII, a "polícia" sofreu uma substancial alteração, mais ligada à "ideia de uma gestão interna racional do Estado, como o instituto de promover sua prosperidade e fortalecimento" (SEELAENDER, 2017, p. 121-122). na forma de administração, eis que passa a valorizar as "novas ciências da sociedade", entre as quais a "ciência da polícia" (Policeywissenschaft, ou science de la police). Estas ciências abrangem a higiene, a segurança e a economia, bem como estavam relacionadas à cameralística (Kameralistik ou ciência da Câmara do monarca), “cujos primeiros tratados são de Delamare, Traité de la Police, 1729, e de Christian Thomasius, Entwurff einer wohnleingerichteten Policey, 1717" (HESPANHA, 2019, p. 333-334).

O termo "polícia", em sentido amplo, como se verificou até o início do XVIII, era a forma de administração das cidades, o conjunto dos meios pelos quais é possível fazer as forças do Estado crescerem, mantendo, ao mesmo tempo, a boa ordem, ou seja, o "esplendor" do Estado. A "polícia” tinha como objetivo assegurar aos homens os bens da alma (religião, posturas e moral), os bens do corpo (saúde, alimentos, liberdade e segurança) e os que são chamados de fortuna (ciências, comércio, manufatura, empregados, trabalhadores e pobres) (DELAMARE, 1722). Em sentido amplo, a "polícia" significou o controle social na ordem interna e a promessa da distribuição da riqueza do Estado. Posteriormente, as atividades de segurança pública interna se restringiram à polícia, como se conhece atualmente, enquanto as

\footnotetext{
${ }^{2} \mathrm{Na}$ Itália, mencionada por BOVA, a Arma dos Carabineiros faz parte do Exército, no que diz respeito aos "problemas hierárquicos e organizativos", portanto subordinado ao Ministério da Defesa, mas também é subordinado ao Ministério do Interior, no que diz respeito "aos deveres de polícia, ao financiamento e operações.” (BOVA, 1998, p. 505). Trata-se de uma instituição híbrida que exerce atribuições policiais, mas pode coadjuvar com o Exército, caso haja necessidade.
} 
demais atividades reguladoras ficaram ao encargo de outros setores da administração. Afirma Hespanha (2019, p. 334-335), citando Adam Smith, que até mesmo a versão liberal se aproveitou bem das ideias de "polícia", enquanto uma instituição que visa aprimorar a técnica de governar, implementando uma regulação preventiva e repressiva.

Exército permanente e "polícia" são instituições modernas, criadas no Estado moderno, portanto, instrumentos de concretização da soberania. A soberania ${ }^{3}$ é elemento que caracteriza o Estado moderno, o seu "coração". A "soberania significa o direito do Estado à decisão última, tanto com referência a questões internas quanto externas." (VOIGT, 2013, p. 105). Na antiguidade e no alto medievo, o conceito de soberania não era conhecido ou desenvolvido tal como ele é entendido hoje. Antes a regra era a existência de vários poderes concorrentes, tais como os espirituais - a Igreja, por exemplo -; os seculares, próprios da organização feudal, as cidades livres, os poderes da nobreza, exercidos localmente etc. O Estado moderno se assentou na soberania para controle territorial e para a legitimidade da autoridade, na pessoa do príncipe, e visou superar a autoridade dos poderes concorrentes. " $\mathrm{A}$ soberania é o poder absoluto e perpétuo investido em uma comunidade que em latim é denominado de majestas" (BODIN, 1606, p. 84, tradução nossa) ${ }^{4}$.

As cidades republicanas, que floresceram no alto medievo, foram, aos poucos, substituídas pelo Estado Nacional, fortemente fundamentadas na soberania do príncipe. "Neste sentido, a República é substituída pela Monarquia, a cidade ideal, pelo Estado moderno" (RODRIGUES; KAMITA, 2018, p. 27). É certo que a soberania não conseguiu, por si só, eliminar os poderes concorrentes, nem possuiu esta pretensão. O Absolutismo não foi incompatível com os estamentos sociais, que permaneceram com suas parcelas de poder, conquanto a majestade aparecesse mais ilustre, quando formalmente reconhecida por seus

\footnotetext{
${ }^{3}$ A palavra soberania é, possivelmente, uma palavra de origem francesa, "la souveraineté", por sua estreita relação com seu autor mais célebre, Jean Bodin. Ele é apresentado, na versão inglesa do seu livro "Les Six Livres de la République" [The Six Bookes of a Commonweale], como "um advogado famoso, e um homem de grande experiência em matéria de Estado" (BODIN, 1606, capa, tradução livre).

${ }^{4}$ Bodin era também um historiador da antiguidade, destacando as associações de seu conceito de "o Ditador Romano", "Harmost de Esparta", "Esymenete da Salonica", "Archus de Malta" e a "Balía de Florença", contudo faz sua própria leitura dos clássicos, o que caracterizou a renovação renascentista. No período do Renascimento moderno, os autores partiam do que existia para "estabelecer um novo modo de leitura e de interpretação desses textos [antigos], procurando dar-lhes vida através de novas questões e novos temas, associando-os aos problemas do homem em seu cotidiano." (RODRIGUES; KAMITA, 2018, p. 29). O Humanismo renascentista é o principal movimento que marcará os períodos entre os séculos XIV e XV e o século XVII, caracterizado pela redescoberta do homem enquanto ser capaz de perfilar sua própria história, separada de Deus, como não foi possível durante a Idade Média. Jean Bodin é bastante enfático quando afirma que "não há ninguém na terra, depois de Deus, maior do que príncipes soberanos" (BODIN, 1606, p. 153, tradução nossa). É evidente, assim, a primazia do poder do príncipe soberano sobre as outras esferas de poder.
} 
súditos unidos (BODIN, 1606, p. 93) ${ }^{5}$. Ainda assim, as relações sociais do período feudal foram severamente alteradas. O príncipe era soberano e restava aos súditos o dever de obediência.

Nesta nova estrutura social, a organização estatal também mudou: "Exército e burocracia, combinados com um sistema geral de impostos, mantinham a autoridade e o poder dos novos agentes da política, o rei passava a ser a referência para os homens, todos agora designados como súditos.” (RODRIGUES; KAMITA, 2018, p. 27). Para Maquiavel, autor dos Discursos sobre a primeira década de Tito Lívio (2014, p. 83-84), os príncipes e as repúblicas que não possuíam exército permanente corriam o risco de manter seus domínios despreparados para a guerra. A preservação do território era responsabilidade exclusiva dos governantes, que deveriam treinar seus cidadãos como soldados. ${ }^{6}$ Assim, justificava-se a necessidade de um exército permanente. O sistema de repressão readquiriu uma nova lógica através de corpos militares permanentes e de uma burocracia, que atraíam a necessidade da tributação, fazendo que a esfera pública se apropriasse de setores até então exclusivamente privados. Na perspectiva secular e temporal, o poder do rei não encontra concorrentes, apesar de conviver com outros estamentos políticos. Por sua vez, o príncipe de um Estado não era poder máximo diante de outras parcialidades territoriais. O máximo poder dentro de um território particularmente vasto dava concretude à ideia de soberania no contexto da formação dos Estados Nacionais e confessava a necessidade de um exército permanente para defendê-lo e de uma burocracia estatal que exige a tributação dos súditos ${ }^{7}$.

\footnotetext{
5 Jean Bodin fala em três limites para o exercício do poder real: direito divino, direito natural e as leis fundamentais do reino (BODIN, 1606, Livro I, Capítulo XVIII, p. 105). Assim, existem vários poderes dentro do mesmo Estado, contudo a soberania dá primazia ao poder do rei em relação aos demais, com os limites próprios da doutrina humanista e renascentista.

${ }^{6}$ Maquiavel ainda destaca que a multiplicidade de chefes é nociva no comando do Exército: "Todo exército deve obedecer a um só comandante, e não a vários." (MAQUIAVEL, 1994, p. 351). O autor demonstra com exemplos práticos que o comando único em matéria militar pode influenciar positivamente na administração das coisas públicas, como foi o caso da campanha militar do Rei Luís XII, em 1500, quando enviou parte de suas tropas à Pisa, visando restituir aquela cidade aos florentinos. Quando a administração das tropas ficou ao encargo de um único comandante, houve coragem e habilidade na administração das coisas importantes. Assim, para Maquiavel, ficou claro que "é menos perigoso encarregar um só homem de uma expedição perigosa - embora seja um homem de capacidade ordinária - do que incumbir dois homens superiormente capacitados, dando-lhes igual autoridade." (MAQUIAVEL, 1994, p. 351). Isto demonstra, em síntese, a importância da cadeia de comando única e clara em operações militares.

${ }^{7}$ A burocracia de um Estado Nacional dependia essencialmente do rei como fonte primária de legitimidade. Contudo, o sentido de legislação encontrou um novo significado no Estado moderno, com a atividade das assembleias (Estados Gerais, na França; Cortes, na Espanha e em Portugal etc.). As assembleias eram divididas em estamentos sociais (nobreza, alto clero, terceiro estado - povos do reino). Estas assembleias se reuniam com alguma frequência, até o século XVII, eram encarregadas de certas matérias: questões fiscais (majoração e criação de tributos), questões relacionadas à guerra, juramento de herdeiros a aprovação das leis fundamentais, como a Lex Salica, que regulamentava os aspectos da vida em sociedade.
} 
O Estado Nacional, gestado durante séculos, no baixo medievo, encontrou seu ápice no final do século XV - que marca a passagem para a Idade Moderna -, e se assenta em bases diferentes das instituições políticas anteriores ${ }^{8}$. Sobretudo, foi nos séculos XV e XVI que se assistiu a crise geral do modelo feudal e a busca por um novo modelo de governança. Trata-se de uma luta que a burguesia levou séculos para vencê-la e para estabelecer sua hegemonia ideológica, na transformação de antigos aparelhos repressivos de Estado em novos: o exército permanente e a polícia moderna (ALTHUSSER, 2019, p. 164-165). A burguesia se tornou a classe dominante, segundo Althusser (2019, p. 156), ao se apoderar dos aparelhos repressivos. Contudo “[...] nenhuma classe dominante pode assegurar sua permanência apenas pela força, precisa granjear não só o livre consentimento dos membros da classe que domina e explora, mas também o livre consentimento de seus próprios membros [...]” (ALTHUSSER, 2019, p. 156). A ideologia jurídica da burguesia é centrada no controle da propriedade e dos meios estatais e na operação da democracia liberal para manutenção da exploração sobre as demais classes. A "ditadura de classe" funcionou, no caso do Estado francês, na forma de "[...] república democrática censitária, depois sob o Império, as monarquias constitucionais, a República, o cesarismo, a república parlamentar e, atualmente, a república presidencial, depois de passar, durante a Ocupação, por um regime fascista.” (ALTHUSSER, 2019, p. 166). Este percurso político também pode ser percebido em outros países que sofreram a influência política e ideológica francesa, como foi o caso do Brasil, ao longo dos séculos XIX e XX.

Com a ascensão do Estado Moderno, é possível identificar "o nascimento de novas formas de relações econômicas e sociais" e de "novas estruturações políticas." (FOUCAULT, 2008, p. 491). A antiga percepção de "razão de Estado", correlata à unificação de todas as soberanias particulares em um império romano, desaparece e dá espaço aos problemas da legitimidade de um soberano sobre um território. Isso atrai a concorrência entre Estados - em específico, no espaço europeu - e a necessidade de reorganização de forças públicas para a proteção do território e a manutenção da ordem interna (e da própria soberania). O exército permanente e a polícia moderna são aparelhos repressivos úteis à aplicação da política do governo burguês. Como afirmou Althusser (2019, p. 165), “[...] apesar de suas pretensões de

\footnotetext{
${ }^{8}$ A vida moderna tem seu alvorecer entre os séculos XIV e XVI e sucumbe no final do século XVIII. De modo resumido: "Os séculos XIV e XV se caracterizavam pela tensão morte e vida, própria de um período de contradições; o século XVI marcava um inversão dessa lógica, com a descoberta do homem e do mundo modernos e a celebração da vida ativa, que o transformariam no Grande Século; tudo isso abria caminho para a associação do século XVII à decadência, no qual vida e morte voltavam a marcar a vida dos homens. Esse esquema se completa pelo retorno da celebração da vida e da razão no século XVIII.” (RODRIGUES; KAMITA, 2018, p. 24).
} 
'servir ao interesse geral' e desempenhar o papel de 'serviço público', também a administração faz parte do aparelho repressivo de Estado." Portanto, as instituições encarregadas da aplicação da força tem como objetivo controlar e sancionar a política do governo burguês ao ponto de reprimir os que não a respeitam.

Ainda que não seja fácil uma identificação entre o pensamento de Foucault, crítico do marxismo, e Althusser, um defensor do marxismo, ambos concordam que nenhum aparelho ideológico pode governar apenas através da repressão. Os aparelhos estatais servem ao adestramento dos corpos humanos na visão de Foucault ou para manutenção da dominação de classe, como pensa Althusser. Os caminhos podem ser diferentes, mas os pontos de chegada são semelhantes: o exército permanente e a polícia moderna serve como instrumentos de poder. Contudo este poder não é entendido em sua concepção jurídica, no binômio legítimoilegítimo, mas em uma concepção não jurídica, em que o poder é disputado visando prevalecer uma ideologia. Nos últimos séculos, a ideologia burguesa tem prevalecido, seja para reorganizar o dissenso provocado pela guerra ou para impor a submissão da classe explorada pela burguesia.

Por isso que se entende, como defende Achille Mbembe (2018, p. 5), que a "[...] soberania reside, em grande medida, no poder e na capacidade de ditar quem pode viver e quem deve viver. [...] Ser soberano é exercer o controle sobre a mortalidade e definir a vida como implementação e manifestação de poder." A burguesia é a classe dominante que manipula os limites da soberania, que, em última análise, estabelece os atributos fundamentais daqueles que possuem a dignidade de viver e elimina os contingentes que devem morrer. A ideia de povo como o conjunto de homens e mulheres livres e iguais, professada pelo ideal liberal de igualdade formal, como tem lugar na ideologia burguesa se há utilidade para o meio de produção capitalista. A escravidão negra, que coisifica o ser humano, e os diversos holocaustos raciais e religiosos são provas do surgimento do "terror moderno" que forneceu parte da base econômica para o desenvolvimento do Estado liberal (MBEMBE, 2018, p. 27 e 43). As guerras contemporâneas do século XXI, em que são utilizados veículos aéreos não tripulados e outras tecnologias avançadas, estipulam que matar se tornou uma questão de alta precisão.

No final do século XVI e na primeira metade do século XVII, com a emergência da "razão de Estado", passou-se a "uma arte de governar cuja racionalidade tem seus princípios e seu domínio de aplicação específico no Estado.” (FOUCAULT, 2008, p. 491). A razão de 
Estado se concretizou em dois grandes conjuntos de saber e tecnologia políticos: (1) uma instituição diplomático-militar, através do qual as forças do Estado foram garantidas por um "sistema de alianças" e pela "organização de um aparelho armado" - consequência direta dos tratados de Vestefália (1648), que buscou um equilíbrio europeu através dos princípios de soberania, territorialidade e não intervenção -; e (2) a "polícia", "no sentido que se dava a essa palavra, isto é, o conjunto dos meios necessários para fazer crescer, do interior, as forças do Estado.” (FOUCAULT, 2008, p. 491).

Como resumiram Hamilton, Madison e Jay (2003, p. 252), “Um dos primeiros objetos do estabelecimento de todas as sociedades civis é a sua segurança contra os perigos externos" "9. Ocorre que a técnica do conjunto diplomático-militar não se resume no exército permanente, nem se restringe à conservação do Estado. Ela visa, principalmente, a manutenção ou o desenvolvimento de uma dinâmica das forças entre Estados soberanos concorrentes. Assim, este sistema permitiu "aberturas suficientes a cada Estado para que possa maximizar sua ampliação sem provocar seus adversários e sem, portanto, acarretar seu próprio desaparecimento ou seu próprio enfraquecimento" (FOUCAULT, 2008, p. 398). Neste sentido, o instrumental diplomático se mostrou essencial para a constituição do equilíbrio entre Estados na Europa e para, na medida do possível, evitar a guerra tradicional ou inseri-la dentro da continuação de uma política pós-tratados de Vestefália.

Esta nova concepção de guerra exigia também o estabelecimento de um dispositivo militar permanente com as seguintes características: (1) a profissionalização do Exército, com a instituição de uma carreira própria; (2) uma estrutura armada permanente, capaz de empregar as tropas recrutadas excepcionalmente em tempo de guerra; (3) um conjunto de fortalezas e transportes militares; (4) uma doutrina e prática de tática militar para melhorar a eficiência das tropas (FOUCAULT, 2008, p. 408-409). O dispositivo militar é, em suma, "um dos elementos essenciais nessa concorrência entre os Estados, em que cada um procura, evidentemente, inverter a relação de força a seu favor, mas que todos querem manter em seu conjunto." (FOUCAULT, 2008, p. 409).

\footnotetext{
${ }^{9}$ A prevenção contra os perigos exteriores é a primeira providência da União, seguindo-se, nesta ordem, as tarefas de: “ $2^{\circ}$ ) regular o comércio com as nações estrangeiras; $3^{\circ}$ ) manter entre os Estados a harmonia e relações convenientes; $4^{\circ}$ ) diferentes objetos mistos de utilidade geral; $5^{\circ}$ ) prevenir os abusos de poder em que poderiam cair os Estados; $6^{\circ}$ ) fazer as leis necessárias para dar a todos esses poderes a eficácia que devem ter" (HAMILTON; MADISON; JAY, 2003, p. 252).
} 
O Estado moderno preparou seu exército permanente para sustentar uma política de equilíbrio europeu, em que a guerra é apenas circunstancial. O mais importante para preservação do Estado foi a aplicação de um complexo diplomático-militar, em que a relação qualitativa entre paz e guerra é condicionada pela política entre Estados soberanos. Por outro lado, a manutenção do exército permanente é dispendiosa em tempos de paz, e precisam ser utilizados, o que aumenta a inclinação para a guerra. Porém, atingidos os objetivos militares, o conflito pode ser encerrado a qualquer momento por meio de um tratado de paz (VOIGT, 2013, p. 107).

O segundo grande conjunto tecnológico, a "polícia", expressou um dos instrumentos da intervenção do poder monárquico frente a dispersão dos poderes feudais (NAPOLI, 2003, p. 35). A "polícia" tinha como objetivo o crescimento do Estado, ao mesmo passo que oferecia aos súditos a "boa ordem” (FOUCAULT, 2008, p. 421). Para o Estado crescer, faz-se necessário que os homens vivam em grandes quantidades e permaneçam vivos pelo maior tempo possível, devendo ir para além da mera subsistência. Aos homens é realizada a promessa de usufruir das vantagens que o Estado possa oferecer. Assim, o Estado criou a "polícia" como "o conjunto das intervenções e dos meios que garantem que viver, melhor que viver, coexistir, será efetivamente útil à constituição, ao aumento das forças do Estado.” (FOUCAULT, 2008, p. 438) ${ }^{10}$. O sistema de controle interno da ordem pública e da disciplina, denominado "polícia", no seu sentido amplo, foi desenvolvido entre os séculos XVI e XVIII. Significou a regulamentação dos aspectos da vida em sociedade, ou seja, a regulamentação de costumes, valores, posturas, comportamentos, regras econômicas, sanitárias, de edificações etc.

Somente em meados do século XIX, com a especialização de funções, a função de "polícia" passou a ser exercida por diversos órgãos estatais, conforme os campos do conhecimento que se mostraram mais eficazes no desenvolvimento de suas respectivas atividades. Assim, a segurança e a manutenção da paz pública passaram a ser atividades da polícia em sentido estrito, enquanto as demais funções ficaram divididas entre as diversas

\footnotetext{
${ }^{10}$ Deve-se esclarecer que o sentido de "polícia" ora trabalhado não se confunde com polícia de segurança pública, polícia em sentido estrito, apesar daquele originário. O conceito de "polícia" é aquele que vigeu até o início do século XIX, em que sua ideia era ainda excessivamente abrangente. Por exemplo, na classificação ampla proposta por Delamare (1722), a "polícia" poderia ser dividida em onze categorias: (1) religião; (2) posturas e moral (moeurs); (3) saúde pública; (4) alimentos e as necessidades da vida; (5) rodovias e a liberdade e segurança dos movimentos ao longo delas; (6) segurança e manutenção da paz pública; (7) as ciências e as artes liberais; (8) comércio; (9) manufatura e artes mecânicas; (10) empregados domésticos, trabalhadores; e (11) os pobres. O antigo sentido de "polícia" sobrevive até hoje na contemporaneidade como "poder de polícia", um dos atributos da Administração Pública.
} 
polícias administrativas, conforme suas áreas de atuação: fiscalização tributária, fiscalização dos setores de ensino, saúde, previdência, profisssões etc. A tarefa de manutenção da ordem pública, destinada à polícia de segurança pública e de repressão a criminalidade, é originária deste sentido amplo de "polícia", e dela é indissociável. A "polícia" foi importante para a consolidação do Estado moderno na medida em que estimulou a justificativa da utilidade estatal e da apropriação pública de espaços até então próprios da vida privada.

\section{A CONTEMPORANEIDADE DO NÃO COETÂNEO, EXÉRCITO E POLÍCIA}

O Estado liberal foi inaugurado com as revoluções liberais do final do século XVIII, alterando as relações de poder através do contratualismo. É introduzida uma construção alternativa ao absolutismo, no espaço europeu, em que se acentuará o protagonismo do homem enquanto portador de direitos naturais, inalienáveis e suprapositivos. Os homens são originalmente livres se reúnem para alienar parte de sua liberdade em favor da construção da sociedade política (Estado). Trata-se da concepção artificial e finalística de Estado, que já estava presente em Hobbes desde o século XVII, mas que irá receber uma nova roupagem com Locke, Montesquieu e Rousseau. Eles acentuaram a doutrina liberal que irá fundamentar as revoluções inglesa, americana e francesa. Estas revoluções combateram a ideologia do absolutismo através do direito de resolução diante dos abusos por parte do poder executivo e da omissão do poder legislativo; da ideia de limitação do poder por meio da separação de poderes; e da ideia de soberania popular.

Em suma, no final do século XVIII, ocorreu, no espaço europeu, uma alteração na formação social hierárquica, que contestou a semântica moral-religiosa da indissociável diferença entre o transcendente e o imanente, que, por sua vez, fundamentava a estrutura política de dominação, reproduzida com base na diferença entre poder superior e poder inferior (NEVES, 2009, p. 6-7). O constitucionalismo revolucionário inicia a diferenciação entre política e direito, no contexto de transformações sociais em que o homem adquire liberdade religiosa e econômica, culminando em um amplo processo de diferenciação sistêmico-funcional em que a sociedade se torna "multicêntrica" ou "policontextual" (NEVES, 2009, p. 23). Nesta conjuntura liberal, o Estado é alçado a "fantasma que atemorizou o indivíduo. O poder, de que não pode prescindir o ordenamento estatal, aparece, de início, na moderna teoria constitucional como o maior inimigo da liberdade" 
(BONAVIDES, 2013, p. 40). Contudo, o argumento da ideologia liberal sobre a necessidade de limitação do Estado não convence. Trata-se apenas de subterfúgio para dominação de classe ou para uma nova forma de reorganização em torno da disputa de poder. O Estado liberal conviveu de modo beligerante com suas contradições: a escravidão negra, a exploração da classe operária, a expropriação sistemática da propriedade dos pequenos produtores, a discriminação contra as mulheres, a perseguição às religiões minoritárias, o extermínio de minorias étnicas, as guerras coloniais e neoliberais, etc.

Essas contradições e o permanente retorno do terror autoritário é a contemporaneidade do não coetâneo. Segundo Pedro Erber, a expressão "contemporaneidade do não contemporâneo" (Gleichzeitigkeit der Ungleichzeitigkeit) foi cunhada pelo filósofo Ernst Bloch nos anos 1930. Bloch tinha o interesse de explicar como o nazifascismo se originava na sociedade alemã do início do século XX, em um contexto em que "se encontravam lado a lado, segundo ele [Bloch], as mais primitivas formas de organização social e as últimas novidades do capitalismo moderno.” (ERBER, 2018, p. 216). De fato, como afirmou Bloch, em um texto escrito em maio de 1932 chamado Summary Transition: non-comtemporaneity and obligation to its dialectic, "Nem todas as pessoas existem no mesmo agora. Eles fazem isso apenas externamente, pelo fato de que podem ser vistos hoje. Mas, portanto, eles ainda não vivem ao mesmo tempo com os outros." (BLOCH, 1991, p. 97, tradução livre) $)^{11}$.

De acordo com Bloch, as pessoas podem carregar consigo elementos anteriores e os tempos mais antigos continuam a ter efeito na contemporaneidade. Isto impõe uma curiosa convivência entre o modo de reprodução social antigo e novo. $O$ antigo não floresce na obscuridade do passado, mas se contradiz com o agora, e pretende se revestir como se fosse o "novo". As posições reacionárias são renovadas e são apresentadas como posições alternativas à teoria liberal para adquirir uma textura que nunca lhes foi própria. A combinação entre a defesa da superioridade de raças - muitas vezes travestida de modalidade formal da igualdade racial pela meritocracia -, a imposição do divino na definição da estrutura social - ignorando a separação multicêntrica entre religião e direito, e religião e política - e a estrita obediência à autoridade absoluta - como forma de assegurar a homogeneidade social e política, ignorando o caráter policêntrico e democrático da sociedade

\footnotetext{
${ }^{11}$ Tradução livre do trecho: "Not all people exist in the same Now. They do so only externally, through the fact that they can be seen today. But they are thereby not yet living at the same time with the others."
} 
- são exemplos de como ideais reacionários podem penetrar no Estado liberal para criticar a separação de poderes e a garantia de direitos fundamentais. O reacionário se reveste da técnica liberal para se contrapor a igualdade e reafirmar a autoridade própria de um regime absolutista que não pode retornar da mesma forma.

A expressão de Bloch foi traduzida para o Brasil como "contemporaneidade do não coetâneo", para marcar a "diferença semântica entre as duas instâncias da mesma palavra alemã” (ERBER, 2018, p. 216). A expressão foi utilizada entre os membros do Instituto Superior de Estudos Brasileiros (Iseb). Erber (2018, p. 216) menciona que Guerreiro Ramos citou Bloch em uma palestra proferida em 1956. De fato, Guerreiro Ramos defendeu no seu livro O Problema Nacional do Brasil que o "Brasil é um país em que se registra a mais eloqüente ilustração da 'contemporaneidade do não coetâneo', pois apresenta 'aspectos bem definidos de todas as etapas do desenvolvimento da sociedade humana"” (RAMOS, 1960, p. 89). Trata-se de uma citação direta de Bloch. De forma semelhante, Nelson Werneck Sodré, outro membro do Iseb, em Formação Histórica do Brasil, utiliza a mesma expressão para explicar os diversos regimes de produção que a sociedade conheceu ao longo do tempo: a comunidade primitiva, o escravismo, o feudalismo, o capitalismo e o socialismo. Sodré destaca que, no Brasil, diversos regimes de produção coexistiram e "ainda hoje [1962] - é a contemporaneidade do não-coetâneo, um dos traços específicos do caso brasileiro, mas não privativo deste caso." (SODRÉ, 2002, p. 14) ${ }^{12}$. O que importa neste trabalho é acentuar que as contradições entre o moderno e o contemporâneo, ou seja, entre as instituições do regime absolutistas e as antigas instituições refundadas no regime liberal, estão presentes no cotidiano. O exército e a polícia de segurança pública são tecnologias oriundas do Ancien Régime, que sobreviveram e foram refundadas no Estado liberal, utilizadas para sustentar os interesses da classe burguesa ou para assegurar o poder nas mãos da burguesia.

Se tratando de uma entidade pública que floresceu no Estado absolutista, o Exército permanente não passou pela observação dos filósofos contemporâneos sem críticas. Hamilton,

\footnotetext{
${ }^{12}$ Sodré ainda destaca que "Coexistem, no Brasil, regimes de produção diferentes, de tal sorte que geram antagonismos por vezes profundos entre regiões do País. Quem percorre o nosso território do litoral para o interior marcha, no tempo, do presente para o passado, conhece, sucessivamente, formas capitalistas de produção e formas feudais ou semifeudais, e pode mesmo conheceu a comunidade primitiva onde os indígenas conservam o tipo de sociedade peculiar, o mesmo que os colonizadores encontraram no século XVI. O fato de que tais regimes já não estejam nitidamente caracterizados e o fato do escravismo, a rigor, esteja extinto, não invalidam tais contrates." (SODRÉ, 2002, p. 14).
} 
Madison e Jay (2003, p. 253), autores de O Federalista, afirmaram que o "século XV foi a época desgraçada dos estabelecimentos militares em tempo de paz", pois Carlos VII de França foi o primeiro a ver a necessidade de exércitos permanentes para afastar o receio de um Estado fraco ou a ambição de outro mais forte, onerando a liberdade dos cidadãos com tributos. Assim, os autores lamentaram que os Estados Unidos da América estariam experimentando uma sorte ainda mais desgraçada do que a da Europa. Os exércitos europeus ficaram restritos a suas condições próprias, enquanto os norte-americanos poderiam ser contaminados pelas rivalidades de outras nações. ${ }^{13}$

O exército, que assegura a preservação do Estado, é o mesmo que reprime a liberdade e traz riscos à prosperidade. No projeto filosófico de Paz Perpétua de Immanuel Kant (2008, p. 6), "Os exércitos permanentes (miles perpetuus) devem, com o tempo, de todo desaparecer", pois "ameaçam incessantemente os outros Estados com a guerra, devido à sua prontidão para aparecerem sempre preparados para ela." Kant explica que, moralmente, pagar um soldo para que homens matem ou sejam mortos é, moralmente, errado, equipara o ser humano a "simples máquinas e instrumentos na mão de outrem [do Estado], uso que não se pode harmonizar bem com o direito da humanidade na nossa própria pessoa.” (KANT, 2008, p. 6).

$\mathrm{Na}$ teoria marxista, o exército ganha uma crítica contundente por se tratar de uma instituição do Estado capitalista, que se desenvolveu no liberalismo econômico. Lênin, em $O$ Estado e a Revolução, afirma que o "Estado aparece onde e na medida em que os antagonismos de classes não podem objetivamente ser conciliados. E, reciprocamente, a existência do Estado prova que as contradições de classe são inconciliáveis." (LÊNIN, 2011, p. 37). O exército e a burocracia são instrumentos da máquina governamental nas mãos da sociedade burguesa (LÊNIN, 2011, p. 64). Os programas dos partidos de esquerda na Alemanha, do final do século XIX, estabeleciam como meta a substituição do exército permanente por uma milícia popular, como foram o Programa de Eisenach (1869), Gotha (1875) e Erfurt (1891). Para estes programas, o fundamental é a instrução para defesa geral, através de uma milícia, eliminando-se o exército permanente (MARX, 2012) ${ }^{14}$.

\footnotetext{
${ }^{13}$ Porém Hamilton, Madison e Jay (2003, p. 255) destacaram que os exércitos permanentes poderiam ficar limitados pela Constituição pelo poder do parlamento, como ocorre na Inglaterra que fixa o orçamento da instituição militar e o número de seu contingente anualmente.

${ }^{14}$ Ocorre que, como bem observado por Marx (2012, p. 42), a reinvindicação de uma milícia popular, como sufrágio universal, legislação direta, direito do povo etc., não passam da "velha cantilena democrática, conhecida de todos", "um mero eco do Partido Popular burguês, da Liga da Paz e da Liberdade."
} 
Da mesma forma, a polícia moderna, oriunda do conjunto tecnológico de "polícia" tem sofrido críticas de filósofos contemporâneos. A polícia totalitária encontra uma crítica veemente em Hannah Arendt. Para a autora, a polícia pode constituir um "único órgão do poder" nos regimes totalitários, diminuindo a atuação do exército a uma política de "aspiração totalitária de domínio mundial e pela consciente abolição da diferença entre um país estrangeiro e o país de origem, entre assuntos externos e assuntos domésticos." (ARENDT, 1989, p. 470). A ideia de preservação da ordem por meio da polícia, no domínio totalitário, submete toda a institucionalidade ao objetivo de atingir a completa amálgama entre o Estado e o partido único, de modo que toda divergência partidária ou organizacional, deve ser eliminada. Neste sentido, os "governantes totalitários tratam os governos não totalitários da mesma forma como tratavam os partidos parlamentares ou as facções intrapartidárias antes de terem tomado o poder (ARENDT, 1989, p. 470). No regime totalitário, o desenvolvimento autônomo do exército não interessa ao domínio totalitário, o que demandou uma maximização da função policial na ditadura do nacional-socialismo e ditadura bolchevista: as polícias secretas submetem inclusive a atuação do exército e condiciona a burocracia à perseguição dos elementos que divirjam do partido totalitário. Neste sentido, “o dever da polícia totalitária não é descobrir crimes, mas estar disponível quando o governo decide aprisionar ou liquidar certa categoria da população.” (ARENDT, 1989, p. 476). No Estado totalitário, a polícia acaba por se constituir a degradação do exército, e submete toda a institucionalidade interna e externa ao conflito permanente.

Derrotado o totalitarismo nazifascista na Segunda Guerra Mundial, e inaugurada a polarização entre capitalismo e comunismo, foram os exércitos que ganharam protagonismo, em especial, nas Américas Latina e Central, na segunda metade do século XX. Na região, foram desenvolvidos um forte sentimento anticomunista e um alinhamento aos países centrais de organização capitalista. Comentando sobre a infeliz história política dos países da América Central, Robert Dahl afirmou que, dos “47 governos da Guatemala, El Salvador, Honduras e Nicarágua entre 1948 e 1982, mais de dois terços obtiveram o poder por meios diferentes de eleições livres e justas - em geral, golpes militares." (DAHL, 2001, p. 165). Por sua vez, a Costa Rica decidiu eliminar seu exército no início da década de 1950, por razões históricas próprias - o desmantelamento da instituição militar após uma grave guerra civil -, e o substituiu por uma polícia nacional, sob controle civil - assim, assegurando o cumprimento da legislação e o controle social -, ao passo, que foi beneficiado com um sistema interamericano 
de alianças militares para defesa do seu território. Como resultado, a Costa Rica, apesar dos problemas econômicos e políticos, não sofreu mais nenhum outro golpe militar desde então.

O dispositivo diplomático-militar dos Estado foi reforçado durante os séculos XIX e $\mathrm{XX}$, em regimes democráticos ou autoritários, de modo indiferente, em face da necessidade de reafirmação dos preceitos de soberania, igualdade jurídica entre os Estados, territorialidade e não-intervenção. Contudo, um Estado que se autodenomina democrático, seja pela constituição jurídica ou pela experiência política, somente pode desenvolver sua institucionalidade democrática se as forças militares e policiais estiverem sob o controle das autoridades civis eleitas (DAHL, 2001, p. 163). Além da monarquia centralizada, da aristocracia hereditária e da oligarquia de sufrágio limitado, na prática política, se mostraram inimigos da democracia, os regimes autoritários comunistas, fascistas e o nazista; bem como as ditaduras militares nas Américas Latina e Central.

As ditaduras latinas adotaram uma fachada pseudodemocrática, pois obstaram as condições mínimas da democracia liberal: (1) funcionários eleitos; (2) eleições livres, justas e frequentes; (3) liberdade de expressão; (4) fontes de informação diversificadas; (5) Autonomia para as associações; e (6) cidadania inclusiva (DAHL, 2001, p. 99). O mal uso do exército permanente para fins autoritários foi demasiadamente frequente nos países periféricos, submetidos ao imperialismo e suas condições particulares, enquanto submetidos ao comando políticos das forças dominantes da sociedade senhorial (latifúndio) e da burguesia em ascensão nas cidades. A ascendência de governos militares na América Latina, como ocorreu no Brasil, Argentina, Chile etc., entre os anos 1960 e 1980, é a prova de que o exército e a polícia de segurança pública podem ser utilizados para uma política antiliberal, em desacordo com a contemporaneidade. No caso brasileiro, o regime militar de 1964-1985 foi muito danoso ao desenvolvimento da democracia, gerando um atraso institucional de décadas até hoje sentido.

Por ocasião do processo de redemocratização, no final dos anos 1980, Sodré defendeu que as Forças Armadas deveriam abandonar as posições extremas e deveria manter um "processo autônomo de desenvolvimento, acima do Estado, neutro ou isolado." (SODRÉ, 1998, p. 86). Sodré ainda ponderou que a democratização da sociedade brasileira é o caminho para a democratização dos meios militares, de modo que "uma Constituição democrática é muito importante para condicionar a democratização das Forças Armadas. Os militares são formalistas: o respeito à lei escrita tem importância para eles.” (SODRÉ, 1998, p. 87). 
Obviamente que uma constituição, por si só, não impede o comportamento autônomos dos militares. A eficácia da constituição está aliada a uma conjuntura mundial mais favorável aos processos democráticos - como se verificou no final da década de 1980, com o colapso do regime comunista na antiga União Soviética e no Bloco do Leste Europeu -, e a um sistema constitucional que dificulte a intervenção militar e suas pretensões autoritárias.

De modo semelhante, a "polícia" não abandonou as suas bases reacionárias, requalificando-se como instituição destinada a manutenção da ordem, acabou por ser utilizada para servir aos interesses da classe burguesa. As suas bases absolutistas começaram a ser corroídas, mas não foram inteiramente afastadas, mesmo em sociedades mais dinâmicas, permeadas pelas ideias liberais, como a francesa (SEELAENDER, 2010, p. 79-80). Em uma acepção ampla, a instituição foi constituída para o controle social, conciliando as modulações da "democracia liberal" e da "democracia iliberal", ao estabelecer as formas de controle estatal contra a desordem e as novidades decorrentes das mudanças sociais (DELUERMOZ, 2012, p. 82). Enfim, a ideia de "polícia" se converteu um instrumento para o estado liberal, mas, na verdade, "a sobrevivência de um termo politicamente tão incômodo é um claro indício de sua maleabilidade e utilidade, tanto no século XIX quanto no período posterior." (SEELAENDER, 2010, p. 81). A polícia continuou a servir para manter a integridade social interna, antes a serviço do príncipe, posteriormente, a serviço dos interesses das classes dominantes burguesas.

A crítica ao subsistema da polícia é contundente. Walter Benjamin, em Para una crítica da violência, defende que a polícia é expressa um poder para fins de execução de medidas jurídicas, mas também estabelece, para si mesma, o direito de executar tais medidas por métodos mais brutais dentro do espaço em que não é possível sindicar suas ações. Neste sentido, a polícia reúne poderes que vão além da possibilidade de análise do direito, assumindo uma presença "espectral, inaferrable y difusa por doquier, en la vida de los estados civilizados". Assim, nas democracias, a polícia "testimonia la máxima degeneración posible de la violencia." (BENJAMIN, 1995, p. 27). Na sua interpretação sobre a doutrina de Benjamin, Luigi Ferrajoli destacou que a polícia reúne prerrogativas próprias de todos os poderes, que decorre "de su función y de su ubicación institucional” (FERRAJOLI, 1995, p. 766). Deste modo, a polícia faz parte do poder executivo por se tratar de uma atividade administrativa formalmente organizada, atua em contato direto com liberdades fundamentais, auxilia a jurisdição e exerce competências próprias e autônomas, preventivas e cautelares 
contra pessoas perigosas e suspeitos. Esta reunião de "forças" se "manifiesta como «violencia», y de ahí proviene su latente ilegitimidad con respecto al paradigma del estado de derecho.” (FERRAJOLI, 1995, p. 766). A polícia escapa de determinações legais claras e pode exercer poderes sem limites evidentes: "Desde este punto de vista, la policía es, al mismo tiempo, una institución moderna y un residuo del ancien régime. (FERRAJOLI, 1995, p. 766).

No Brasil, a "polícia" foi instituída para o controle interno da sociedade, em especial, no ambiente urbano, em que as relações sociais tendem a ficar mais complexas. A manutenção da ordem, através dos modelos policiais que privilegiam os interesses das elites, proporcionou um modelo civilizacional excludente em relação à construção da cidadania e da relação entre Estado e sociedade (COTTA, 2012). Em outros termos, o Estado liberal foi instalado para combater os privilégios da realeza e da nobreza, fortemente idealizados em direitos fixados por estamentos e na fundamentação transcendente da autoridade divina, que impossibilitava a diferenciação funcional entre política e direito. Contudo, a ascensão da classe burguesa exigiu a requalificação da "polícia" para dar cabo ao cumprimento da lei e da ordem, moldadas pela elite. A elas interessava a "polícia" para o controle das classes operárias, das massas eleitorais e das classes perigosas - constituídas pelos pobres, os marginalizados e os indesejados -, no decorrer dos séculos XIX e XX, técnica que permanece até a atualidade.

A ascensão da liberdade individual, da limitação de poderes e da garantia de direitos fundamentais precisou conviver com a utilização da "polícia" para controle interno e para assegurar os interesses das classes dominantes, burguesa e senhoriais. A prática policial preenche as lacunas da lei, construindo a realidade de acordo com os critérios totalmente intrínsecos à sua própria racionalidade, que escapam à coerência de uma arquitetura jurídica piramidal, de acordo com o modelo projetado por Hans Kelsen, enquanto também diferenciada da ideia de ruptura prevista por Schmitt (NAPOLI, 2003). Assim, a polícia torna a própria percepção de "normal" mais desfocada e resumida à "arte de governar" (NAPOLI, 2003, p. 435-436). Por assumir feições contraditórias entre o Antigo regime e o Estado liberal, a polícia pode se expressar como uma instituição sem limites determináveis.

\section{CONSIDERAÇÕES FINAIS}


Exército permanente e "polícia", ao lado da diplomacia, da burocracia e da tributação, são instituições que auxiliaram no desenvolvimento do Estado moderno. Estas instituições asseguraram os meios para que o príncipe pudesse prevalecer perante outros poderes concorrentes no mesmo território, ao mesmo passo que proporcionaram ferramentas para fazer frente aos príncipes soberanos dos demais Estados, no espaço europeu. Estas organizações surgiram no bojo da crise da feudalidade e das transformações sociais que favoreceram o desenvolvimento dos Estados Nacionais, cujos aparelhos repressivos foram capturados pela ideologia burguesa, para submissão das classes exploradas ou para reorganização do dissenso provocado pela disputa do poder.

Sob o referencial teórico de Althusser e Foucault, ficou evidente que as instituições ora estudadas constituíram dois importantes conjuntos repressivos de saber e tecnologia políticos. O Exército, por si só, já não era suficiente, no espaço europeu. A diplomacia passou a assegurar o equilíbrio entre os Estados, através do qual se introduziu os princípios de soberania, territorialidade e não intervenção, em especial, a partir de 1648 com os tratados de Vestefália. Ao lado da estratégia diplomática, o Exército permanente constituiu o corpo militar do Estado Nacional, que defende o território e assegura melhores condições para a negociação da paz por ocasião da guerra e um novo equilíbrio de forças, como se a política fosse a guerra prolongada por outros meios.

Este equilíbrio favoreceu o desenvolvimento do outro conjunto tecnológico, a "polícia", entendido no seu sentido amplo, como uma nova forma de administração, notadamente, no meio urbano. A "polícia” tinha como objetivo o esplendor interno do Estado, a garantia da boa ordem e a prosperidade dos súditos, a promessa de um melhor viver para além da mera subsistência. A "polícia" significou um crescimento da administração pública em setores até então exclusivos de espaços privados, na medida em que impôs costumes, valores, posturas, comportamentos, regras econômicas, sanitárias, de edificações etc. A polícia de segurança pública encontrou sua especialização em meados do século XIX, enquanto as demais tarefas ficaram ao encargo de outras esferas públicas.

A crítica e as contradições das instituições coercitivas do Estado se verificaram a partir da ascensão do Estado liberal, em que ficou evidente a "contemporaneidade do não contemporâneo". Esta expressão indica a existência de facetas distintas e a convivência contraditória e incomensurável do antigo com o novo regime. A expressão foi traduzida no Brasil como "contemporaneidade do não coetâneo" e acolhida por intelectuais do Iseb 
para explicar como meios de produção tão diversos, antigos e novos, conviviam no Brasil, ao mesmo tempo, marcando, inclusive evidentes diferenças regionais.

O Exército permanente sofre críticas do liberalismo, do idealismo e do marxismo, por razões diversas: a instituição pode sufocar a liberdade mediante a tributação; a paz perpétua kantiana demanda a extinção dos exércitos; e a instituição é um dos instrumentos da burguesia para oprimir a classe trabalhadora. No âmbito dos países periféricos, o Exército serviu para atentar a separação de poderes e a garantia de direitos fundamentais, tão caros ao Estado liberal, como se verificou, na segunda metade do século XX, em diversos países da América Central e da América Latina. Portanto, a instituição, que deveria assegurar a integridade externa do território, acabou por interferir nos processos políticos internos e por atentar contra a organização democrática das nações naquele espaço geográfico.

A "polícia" também sofreu críticas que expuseram suas contradições com o Estado liberal. Ainda no Estado liberal, a "polícia" acentuou suas funções de controle social, para proteção dos interesses das classes dominantes, negando direitos elementares dos extratos sociais menos favorecidos. No Estado totalitário, a polícia foi o principal instrumento político de consecução do terror autoritário de eliminação de divergências, de aprisionamento e eliminação de certas categoriais populacionais. No Brasil, os modelos policiais proporcionaram um modelo civilizatório de exclusão social e colaboraram para obstar a construção da cidadania e das relações entre Estado e sociedade.

Deste modo, a construção de uma teoria sobre o Exército permanente e a "polícia" passa por reconheceu seus aspectos contraditórios, mas se justificam na medida em que são utilizados como aparelhos repressivos para a promoção da ideologia burguesa ou para regular a disputa pelo poder. Trata-se de instituições que transitam entre o Ancien Régime, que os criou, e Estado liberal que os refundou, mas que não eliminou suas funções primordiais que justificaram sua constituição: a racionalidade da arte de governar pelo Estado moderno.

\section{REFERÊNCIAS BIBLIOGRÁFICAS}

ALTHUSSER, Louis. Iniciação à filosofia para não filósofos. Tradução: Rosemary Costhek Abílio. São Paulo: WMF Martins Fontes, 2019.

ARENDT, Hannah. As origens do Totalitarismo. Tradução: Roberto Raposo. São Paulo: Companhia das Letras, 1989.

BENJAMIN, Walter. Para una crítica de da violencia. Traducido del inglés: Héctor A. Murena. Buenos Aires: Editorial Leviatán, 1995. 
BODIN, Jean. The Six Bookes of a Commonweale. Out of the French and Latine Copies done into English by Richard Knolles. Imprinted at London by Adam Iflip: Imprensis G. Bishop, 1606. (University of London: Presented by the Worshipful Company of Goldsmiths, 1903).

BOVA, Sérgio. Forças Armadas (verbete). In BOBBIO, Norberto; MATTEUCCI, Nicola; PASQUINO, Gianfranco. Dicionário de Política. 1 ed. Tradução: Carmem C, Varriale et al. Brasília: Editora Universidade de Brasília, 1998.

BLOCH, Ernst. Heritage of our times. Translated by Neville and Stephen Plaice. Berkley and Los Angeles: University of California Press, 1991.

BONAVIDES, Paulo. Do Estado liberal ao Estado social. 11 ed. 2 tir. São Paulo: Malheiros, 2013.

COTTA, Francis Albert. Matrizes do Sistema Policial Brasileiro. Belo Horizonte: Crisálida, 2012.

DAHL, Robert A. Sobre a Democracia. Tradução: Beatriz Sidou. Brasília: Editora Universidade de Brasília, 2001.

DELAMARE, Nicolas de. Traité de la police. 2.ed. Paris: [s.n.], 1722.

DELUERMOZ, Quentin. Capitales policières, État-nation et civilisation urbaine: Londres, Paris et Berlin au tournant du XIX ${ }^{\mathrm{e}}$ siècle. In Revue d'histoire moderne \& contemporaine, Paris, $\mathrm{n}^{\circ}$ 60-3, p. 55-85, 2013.

ERBER, Pedro. Jamais fomos contemporâneos: a antropofagia de cá pra lá. Quadranti Rivista Internazionale di Filosofia Contemporanea. Volume VI, nº 1, p. 199-220, 2018.

FERRAJOLI, Luigi. Derecho y razón: Teoría del garantismo penal. Tradución: Perfecto André Ibáñz et al. Madrid: Editorial Trotta, 1995.

FOUCAULT, Michel. Segurança, Território, População: curso dado no Collège de France (1977-1978). Tradução: Eduardo Brandão. São Paulo: Martins Fontes, 2008.

HAMILTON, Alexandre; MADISON, James; JAY, John. O Federalista. Tradução: Hiltomar Martins Oliveira. Belo Horizonte: Ed. Líder, 2003.

HESPANHA, António Manuel. Cultura Juridica Europeia: síntese de um milénio.

Coimbra: Almedina, 2019 [reimpressão].

KANT, Immanuel. A Paz Perpétua: um projecto filosófico. Tradução: Artur Morão. Covilhã, Portugal: Universidade da Beira Interior, 2008 (Colecção: Textos Clássicos de Filosofia).

LÊNIN, Vladimir Ilich. O Estado e a Revolução. Introdução: Francisco Máuri de Carvalho Freitas. Campinas, SP: DE/UNICAMP, 2011. 
MAQUIAVEL, Nicolau. Discursos sobre a primeira década de Tito Lívio. Tradução: Sérgio Bath. Brasília: Editora Universidade de Brasília, 1994.

MARX, Karl. Reflexões sobre o programa de Gotha. Tradução: Rubens Enderle. Prefácio: Michael Löwy. São Paulo: Boitempo Editorial, 2012.

MBEMBE, Achille. Necropolítica: biopoder, soberania, estado de exceção, política da morte. Tradução: Renata Santini. São Paulo. N-1 edições, 2018.

NAPOLI, Paolo. Naissance de la police moderne: pouvoir, norme, société. Paris: La Découverte, 2003.

NEVES, Marcelo. Transconstitucionalismo. 1 ed., 5 tir. [2018]. São Paulo: Editora WMF Martins Fontes, 2009.

RAMOS, Guerreiro. O Problema Nacional do Brasil. 2 ed. Rio de Janeiro: Editora Saga, 1960.

RODRIGUES, Antônio Edmilson M.; KAMITA, João Masao. História Moderna: os momentos fundadores da cultura ocidental. Petrópolis, RJ: Vozes, Rio de Janeiro: Editora PUC, 2018 (Série História Geral).

SEELAENDER, Airton Lisle Cerqueira Leite. A "Polícia" e as Funções do Estado - Notas sobre a Polícia do Antigo Regime. Revista da Faculdade de Direito (UFPR), Curitiba, v. 49, p. 73-87, 2010.

A "Polícia" e o Rei-legislador: notas sobre algumas tendências da legislação portuguesa no Antigo Regime. Eduardo C. B. Bittar (org.). História do direito brasileiro. 4 ed., rev., modif., e ampl. São Paulo: Atlas, 2017.

SODRÉ, Nelson Werneck. Formação Histórica do Brasil. 14 ed. Rio de Janeiro: Graphia, 2002 (Memória Brasileira: 6).

Tudo é política: 50 anos do pensamento de Nelson Werneck Sodré em textos inéditos em livro e censurados. Ivan Alves Filho (org.). Rio de Janeiro: Mauad, 1998.

VOIGT, Rüdiger. Quem é o soberano?: sobre um conceito-chave na discussão sobre o Estado. Revista de Sociologia e Política. Curitiba, v. 21, n 46, p. 105-112, jun. 2013. 